\title{
A survey on measuring the effect of website on customer satisfaction
}

\author{
Naser Azad ${ }^{\mathrm{a}}$ and Amir Esmaeili ${ }^{\mathrm{b}^{*}}$
}

${ }^{a}$ Department of Management, Islamic Azad University, South Tehran Branch, Tehran, Iran

${ }^{b}$ Department of Management, Islamic Azad University, Arak Branch, Arak, Iran

\begin{tabular}{l}
\hline A R T I C L E I N F O \\
\hline Article history: \\
Received December 25, 2011 \\
Received in Revised form \\
March, 25, 2012 \\
Accepted 24 April 2012 \\
Available online \\
April 28 2012 \\
\hline Keywords: \\
Website \\
Customer satisfaction \\
Customer loyalty \\
Information Technology
\end{tabular}

\section{A B S T R A C T}

\begin{abstract}
During the past few years, there has an increasing trend on using internet facilities to do different personal banking. People transfer money, pay their bills and even purchase shares of different companies using internet. There is also an increasing competition among banks and other financial institutions through providing new web based facilities. There is no doubt that a bank with no online banking can easily lose market share. The primary purpose of this paper is to investigate how a bank website can impact customer loyalty. The proposed study is implemented for one of governmental Iranian banks called Bank of Industry and Mine. The study distributes a questionnaire among 330 people who use the internet banking of this bank. We then analyze their feedback using structural equation system and all the hypothesis are confirmed.
\end{abstract}

(C) 2012 Growing Science Ltd. All rights reserved.

\section{Introduction}

Internet has been one of the most popular facilities among new generation and it has been able to break borders among different countries. Online banking is one of the most frequently used options used among many people in the world (Espejel et al., 2008; Voorveld et al., 2009; Wang \& Wu, 2012). It makes it easy to pay bills, receive banking transactions, make an easy investment and virtually reduce unnecessary transportation to banks. Today, there is no doubt that no bank can stay on business unless it uses online banking services. During the past few years, there have been many studies associated with the relationship between e-business and customer loyalty. Athanassopoulou et al. (2004) investigated the impacts of effective communication with lead customers in developing new banking products. The results presented in their study identified communication skills related to successful new service development. They studied nine UK-based commercial banks and realized that the most successful developers implement special skills for communicating with customers more specifically with "lead customers", throughout the development process.

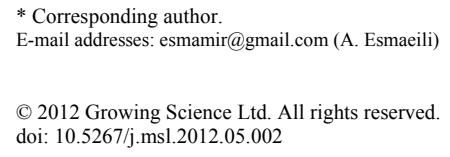


Sheng and Liu (2010) performed an empirical investigation on the impact of e-service quality on online customer satisfaction and loyalty in China. They reported that efficiency and fulfillment had positive impacts on customer satisfaction, and fulfillment and privacy had positive influence on customer loyalty. However, they investigated other factors but reported no significant impact on either customer satisfaction or customer loyalty although they claimed that customer loyalty was positively affected by customer satisfaction. Finding the obstacles to reach the organization's objective such as online trading is also an important issue (Casaló et al., 2008; Setthasakko, 2009; Ghose, 2009; de Matos et al., 2009). Cheung et al. (2008) studied the influence of electronic wordof-mouth using the adoption of online opinions in online customer communities. They found that comprehensiveness and relevance to be the most effective components of the argument quality construct of the research model, making them key influencers of information adoption.

Customer is the last person who says the last word for the success of firm. If customers are satisfied perfectly, business will be likely profitable. Athanassopoulos et al. (2001) investigated the effect of customer satisfaction on customers' behavioral feedbacks. The results confirmed the notion of direct impacts of customer satisfaction on three criterion variables including decision to stay with the existing service provider, engagement in word-of-mouth communications, and intentions to switch service providers. Wang and Wu (2012) studied the impact of corporate image, perceived value, and switching expenditures on customer loyalty in customer/provider relationships of various length. Their results indicated that corporate image influences customer loyalty in both newer and older relationships. Whereas in newer relationships, corporate image has a cardinal impact on switching expenditures, in more-established relationships switching expenditures are impacted primarily by perceived value and in both cases, switching expenditures impact customer loyalty.

Mcmullan and Gilmore (2008) performed an empirical study on customer loyalty and recognized the relative importance customer loyalty has for various competitive organizations and industries. However, there has been less concentration on what value customer's attach to customer loyalty in this context. Torres-Moraga et al. (2008) studied customer satisfaction and loyalty from start with the product to culminate with the brand. The results indicated that the relationship satisfaction-loyalty is substantially present when evaluating products alone albeit a weaker presence than when evaluating brand alone. Such unequal presence is corroborated in both conventional and electronic products even though it is much stronger in innovative products. The relationship satisfaction-loyalty is also present when evaluating product and brand combined, indicating that there is an intermediate position between product and brand.

Dholakia and Zhao (2010) studied the impacts of online store characteristics on customer satisfaction and repurchase intentions. They identified website characteristics, which influence customer evaluations and satisfaction with online stores at two interaction points from the time the order is placed till the time the order has been fulfilled. They collected the necessary data from bizrate.com and the analysis was concentrated on the changes in the relationships between website characteristics and customer ratings. They reported that order fulfillment variables, particularly on-time delivery, dominate the impact on overall customer evaluations and satisfaction. Law and Bai (2008) investigated on how the preferences of online buyers and browsers differ on the design and content of travel websites. Their empirical results indicated that travel website users viewed quality factors important, and they were satisfied with travel websites. Although these website users had a positive view for purchase intention in the long term, there were significant changes between the two groups of users in all attributes of customer satisfaction and purchase intention. Most specifically, research findings indicated that travel website quality factors were positively correlated to customer satisfaction, which in turn, was significantly correlated to purchase intention.

Muňoz-Leiva et al. (2010) studied on how to improve trust toward electronic banking and more specifically, they studied trust towards a bank and its dependability using a variety of "institution- 
based" trust mechanisms, such as security of transaction, reputation and web quality. They reported that the mere presence of seals was not in itself important for the explanation of beliefs about trustworthiness and dependability of a website with electronic banking services. Dimitriadis and Stevens (2008) performed an internal/external gap model for integrated customer relationship management for service activities. They summarized key results of previous research on customer relationship management (CRM) internal success/failure factors, adds a customer perspective on CRM expectations and perceptions, and links these internal and external factors using a systemic gap approach. They reported that viewing a relationship as a value and as a quality driver could lead managers to consider expectations as a tool to design good interaction flows with customers.

Vanniarajan and Gurunathan (2009) studied service quality, customer satisfaction and behavioral intention in rural banking. They proposed a new technique for evaluating the effect of quality in rural banking on customer satisfaction and their behavioral intention based on SERVPERF scale. The results of their study disclosed that the important discriminant quality factors among lower income and higher income crops in rural banking were service quality and functional quality. The highly influencing quality dimensions on the customer satisfaction and behavioral intention are service quality and personnel quality. Therefore, the study explained the importance of internal service quality to deliver the better service quality to their customers.

Kassim and Abdullah (2010) performed a cross cultural analysis to study the impact of perceived service quality dimensions on customer satisfaction, trust, and loyalty in e-commerce settings. They found that perceived service quality had a significant impact on customer satisfaction. In turn, customer satisfaction was found to have a significant effect on trust. Both customer satisfaction and trust had significant influences on loyalty through word of mouth (WOM). Longart (2010) in other study investigated the effects of WOM on internet websites. O'Reilly and Marx (2011) studied how young, technical consumers evaluate online WOM credibility. Sweeney et al. (2012) emphasized on the relative importance of WOM.

In this paper, we investigate the impact of online banking through website on customer loyalty. The proposed study is implemented for one of governmental Iranian banks called Bank of Industry and Mine. The organization of this paper first presents details of hypothesis in section 2. Section 3 presents details of our finding and concluding remarks are given in the last section to summarize the contribution of the paper.

\section{The proposed study}

The proposed study is implemented for one of governmental Iranian banks called Bank of Industry and Mine. The study distributes a questionnaire among 330 people who use the internet banking of this bank. There are four hypotheses with the proposed study of this paper, which are as follows,

1. Internet usage has positive impact on customer satisfaction.

2. Customer satisfaction has positive relationship with customer loyalty.

3. Customer satisfaction has positive impact on long-term relationship.

4. Customer loyalty has positive impact on long-term relationship.

In this study, we have used four variables of customer satisfaction (ST), customer loyalty (LY), effective relationship (EC) and using the website (UWB). We have adopted a standard questionnaire based on Likert scale and it was distributed among 330 people. We have used structural equations using LISREL software package and Cronbach alpha was calculated as 0.906, which is well above the minimum desirable level, 0.70. Fig. 1 shows details of our proposed structural equations. The proposed framework is adopted from the work, which has recently accomplished by Casaló et al. 
(2008), which was an investigation on the role of satisfaction and website usability in developing customer loyalty and positive word-of-mouth in the e-banking services.

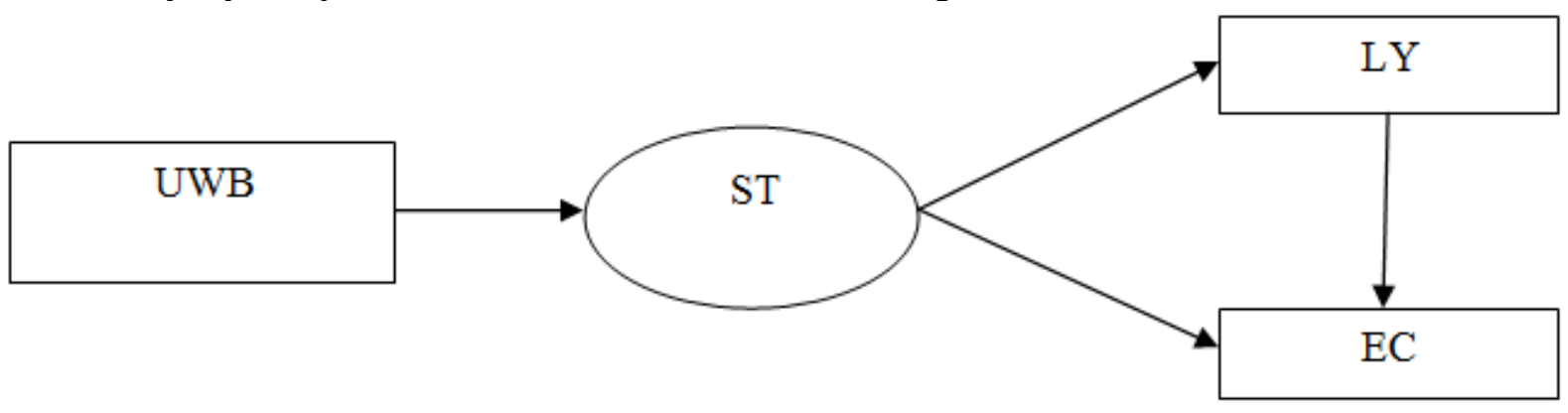

\section{The results}

Fig. 1. The proposed framework (Casaló et al., 2008)

In this section, we present details of our computations using LISREL software package. Fig. 2 shows details of coefficients.

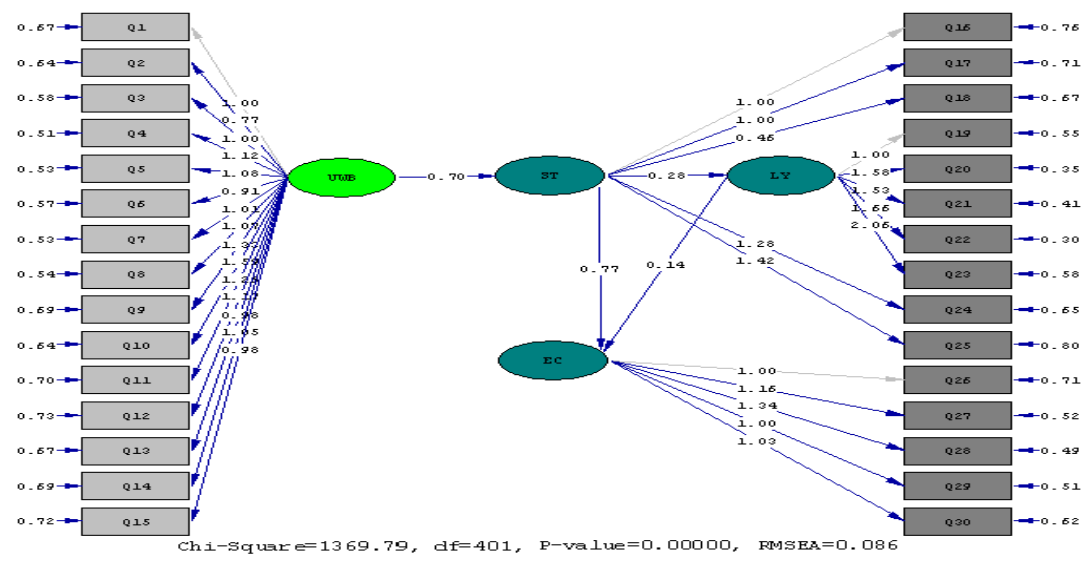

Fig. 2. Standard coefficients of structural equations

As we can observe from the results of Fig 2, RMSEA represents a meaningful value for the proposed study. Fig. 3 shows details of t-student values for the proposed study.

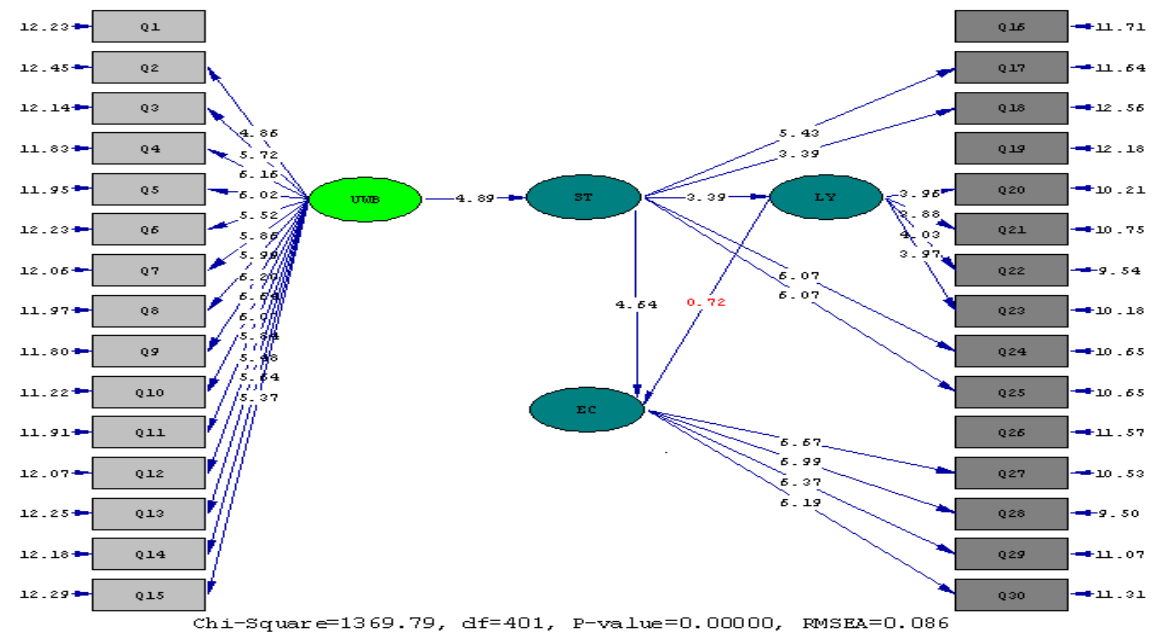

Fig. 3. The results of t-student 
As we can observe from the results of Fig. 3, all t-student values are well above the desired level when the level of significance is 0.05 . In addition, Table 1 shows details of other important figures associated with the proposed study of this paper.

\section{Table 1}

The results of statistical observations

\begin{tabular}{ccc}
\hline Macro & Standard numbers & Predicted numbers \\
\hline Degrees of Freedom & ------- & 401 \\
Chi-Square & Since there are limited number of sample size it is not a reliable number & 1369.79 \\
RMSEA & 0.05 & 0.086 \\
NFI & 0.90 & 0.77 \\
NNFI & 0.90 & 0.82 \\
CFI & 0.90 & 0.84 \\
RMR & 0.05 & 0.068 \\
GFI & 0.90 & 0.78 \\
AGFI & 0.90 & 0.75 \\
\hline
\end{tabular}

The first hypothesis of this research was that there was a positive and meaningful relationship between customer satisfaction and website usage and this hypothesis is confirmed since we have $t=4.89, \gamma_{1}=0.70$ when the level of significance is 0.05 . The second hypothesis of this research was that there was a positive and meaningful relationship between customer satisfaction and customer loyalty and this hypothesis is also confirmed since we have $t=3.39, \beta_{11}=0.28$ when the level of significance is 0.05 . The third hypothesis is associated with the positive relationship between customer satisfaction and continues website usage. Since we have $t=4.64, \beta_{12}=0.77$ we can confirm the third hypothesis when the level of significance is 0.05 . Finally, the last hypothesis specifies that customer loyalty has positive impact on direct and continuous usage of website and since we have $t=0.72, \beta_{3}=0.14$ we cannot confirm the last hypothesis and there is no direct relationship between these two items.

In summary, we can conclude that using a reliable website can contribute significantly on customer satisfaction and loyalty since it provides different advantages such as saving cost and time.

\section{Conclusion}

In this paper, we have presented an empirical study to investigate the impact of having reliable website on improving customer satisfaction and building long-term relationship with customers to make them happy about the services. The proposed study used a standard questionnaire and distributed among 330 people who used internet banking. We have concentrated on customers who were more involved with Bank of Industry and Mine. The results indicated that there was a positive and meaningful relationship between customer satisfaction and website usage, there was a positive and meaningful relationship between customer satisfaction and customer loyalty and there was a positive relationship between customer satisfaction and continues website usage. We hope the results of this paper could contribute e-business and more people use internet facilities to increase the productivity and efficiency of their lives.

\section{Acknowledgement}

The authors would like to thank the officials of Bank of Industry and Mine for providing the necessary support on this work. We are also grateful for constructive comments on earlier version of this work. 


\section{References}

Athanassopoulos, A., Gounaris, S., \& Stathakopoulos, V. (2001). Behavioural responses to customer satisfaction: an empirical study. European Journal of Marketing, 35(5/6), 687-707.

Athanassopoulou, P., \& Johne, A. (2004). Effective communication with lead customers in developing new banking products. The International Journal of Bank Marketing, 22(2), 100-125.

Casaló, L.V., Flavián, C., \& Guinalíu, M. (2008). The role of satisfaction and website usability in developing customer loyalty and positive word-of-mouth in the e-banking services. The International Journal of Bank Marketing, 26(6), 399-417.

Cheung, C.M.K., Lee, M.K.O., \& Rabjohn, N. (2008). The impact of electronic word-of-mouth: The adoption of online opinions in online customer communities. Internet Research, 18(3), 229-247.

de Matos, C.A., Henrique, J.L., \& de Rosa, F. (2009). The different roles of switching costs on the satisfaction-loyalty relationship. International Journal of Bank Marketing, 27(7), 506-523.

Dholakia, R.R., \& Zhao, M. (2010). Effects of online store attributes on customer satisfaction and repurchase intentions. International Journal of Retail \& Distribution Management, 38(7), 482496.

Dimitriadis, S., \& Stevens, E. (2008). Integrated customer relationship management for service activities: An internal/external gap model. Managing Service Quality, 18(5), 496-511.

Espejel, J., Fandos, C., \& Flavián, C. (2008). Consumer satisfaction: A key factor of consumer loyalty and buying intention of a PDO food product. British Food Journal, 110(9), 865-881.

Ghose, K. (2009). Internal brand equity defines customer experience. Direct Marketing: An International Journal, 3(3), 177-185.

Law, R., \& Bai, B. (2008). How do the preferences of online buyers and browsers differ on the design and content of travel websites? International Journal of Contemporary Hospitality Management, 20(4), 388-400.

Longart, P. (2010). What drives word-of-mouth in restaurants? International Journal of Contemporary Hospitality Management, 22(1), 121-128 .

Kassim, N., \& Abdullah, N. A. (2010). The effect of perceived service quality dimensions on customer satisfaction, trust, and loyalty in e-commerce settings: A cross cultural analysis. Asia Pacific Journal of Marketing and Logistics, 22(3), 351-371

Mcmullan, R., \& Gilmore, A. (2008). Customer loyalty: an empirical study. European Journal of Marketing, 42(9-10), 1084-1094.

Muňoz-Leiva, F., Luque-Martìnez, T., \& Sánchez-Fernández, J. (2010). How to improve trust toward electronic banking. Online Information Review, 34(6), 907-934.

O'Reilly, K., \& Marx, S. (2011). How young, technical consumers assess online WOM credibility. Qualitative Market Research: An International Journal, 14(4), 330-359.

Sheng, T., \& Liu, C. (2010). An empirical study on the effect of e-service quality on online customer satisfaction and loyalty. Nankai Business Review, 1(3), 273-283.

Setthasakko, W. (2009). Barriers to implementing corporate environmental responsibility in Thailand: A qualitative approach. International Journal of Organizational Analysis, 17(3), 169-183.

Sweeney, J.C., Soutar, G.N., \& Mazzarol, T. (2012). Word of mouth: measuring the power of individual messages. European Journal of Marketing, 46(1/2), 237-257.

Vanniarajan, T., \& Gurunathan, P. (2009). Service Quality, Customer Satisfaction and Behavioural Intention in Rural Banking. Invertis Journal of Management, 1(1), 13-26.

Voorveld, H.A.M., Neijens, P.C., \& Smit, E.G. (2009). Consumers' responses to brand websites: an interdisciplinary review. Internet Research, 19(5), 535-565.

Torres-Moraga, E., Vásquez-Parraga, A.Z., \& Zamora-González, J. (2008). Customer satisfaction and loyalty: start with the product, culminate with the brand. Journal of Consumer Marketing, 25(5), 302-313.

Wang, C.Y., \& Wu, L.W. (2012). Customer loyalty and the role of relationship length. Managing Service Quality, 22(1), 58-74. 